\title{
Education for Peace What Building Peace Means
}

\author{
Oscar Daniel Franco Conforti \\ Principal Investigator Principal Galtung Istitut Spain (IG-España) \\ Lecturer in Negotiation at the Department of Law and Political Science, Open University of Catalonia, Spain. \\ conforti@me.com
}

\begin{abstract}
The idea of a society without conflicts is not a utopia, however, no less certain is that a priori social peace is only imaginable in a world of individuals who live in a space without any shortage and who have neither ambition nor greed to try to achieve new goals or objectives, this comes to say that jurists must, from their field, make significant contributions to achieve that objective: social peace. But peace has two distinct senses: negative and positive peace. By negative peace, we will understand the absence of violence, negative peace is conflict transformation, so that violence (direct, structural and cultural) stops, full stop (and we must be very careful about that because these forms of violence are interrelated and mutually reinforcing), this concept is complemented by positive peace which is cooperation for mutual and equal benefit, and the word equal is very important here because brings us closer to the harmony concept. In that sensewell know is the Galtung's 3Rs: reconstruction of peoples and places alter the violence, reconciliation of the parties in conflict and resolution of animosities. The present article does not seek to develop any of these issues in-depth but rather to establish the basis for understanding the concept of peacebuilding.
\end{abstract}

Keywords: education for peace; peace concepts; peacekeeping; peacemaking; peacebuilding

\section{Introduction}

In his last editorial Johan Galtung said: "The purpose of peace research is to produce inter-subjectively communicable and verifiable knowledge according to the general rules of research. Thus, research is incompatible with secrecy, as it has to take place in public space." (Galtung, 2019), then paraphrasing Johan Galtung, with the intention of broadening his thinking, it can be said that this concept of inter subjectivity (according to the general rules of research), its incompatibility with secrecy and public spaces has been the purpose of any type of research.

It should be noted at the outset that Peace is a goal which can readily be pursued if the personal and political will exists to set aside their differences for the sake of peace.

The peace concept. Let's take the following two definitions as a starting point:

The first one defines Peace as: "The absence of suffering and the presence of fulfillment; in the nature, human, social and world spaces." (Galtung, 2013: 22).

The second one says:

Peace has two well-differentiated aspects and at the same time absolutely interdependent, on the one hand, as absence of conflict, it entails the deconstruction of the same one, and on the other hand, it implies to strengthen the collaboration, integration, cohesion, and harmony of all the members of the society. (Conforti, 2018, p. 10).

The term peacebuilding was introduced by Johan Galtung in 1975 coined in the article "Three Approaches to Peace: Peacekeeping, Peacemaking, and Peacebuilding." saying that:

[...] peace has a structure different from, perhaps over and above, peacekeeping and ad hoc peacemaking [...] The mechanisms that peace is based on should be built into the structure and be present as a reservoir for the system itself to draw up [...] More 
specifically, structures must be found that remove causes of wars and offer alternatives to war in situations where wars might occur.(Galtung, 1976).

\section{Review of Literatures}

Let's start the study by reviewing a list of selected definitions I take from the Alliance for Peacebuilding (Alliance for Peacebuilding, 2013).

\subsection{Academic Definitions of Peacebuilding}

A. Johan Galtung: Peacebuilding is the process of creating self-supporting structures that "remove causes of wars and offer alternatives to war in situations where wars might occur." Conflict resolution mechanisms "should be built into the structure and be present there as a reservoir for the system itself to draw upon, just as a healthy body has the ability to generate its own antibodies and does not need ad hoc administration of medicine."

B. John Paul Lederach: Peacebuilding is understood as a comprehensive concept that encompasses, generates, and sustains the full array of processes, approaches, and stages needed to transform conflict toward more sustainable, peaceful relationships. The term thus involves a wide range of activities that both precede and follow formal peace accords. Metaphorically, peace is seen not merely as a stage in time or a condition. It is a dynamic social construct.

C. Joan B. Kroc Institute for Peace \& Justice, University of San Diego. Strategic Peacebuilding Principles:

(3.1) Peacebuilding is complex and has multiple actors.

(3.2) Peacebuilding requires values, goals, commitment to human rights and needs.

(3.3) Peacebuilding goes beyond conflict transformation.

(3.4) Peacebuilding cannot ignore structural forms of injustice and violence.

(3.5) Peacebuilding is founded on an ethic of interdependence, partnership, and limited violence.

(3.6) Peacebuilding depends on relational skills.

(3.7) Peacebuilding analysis is complex; underlying cultures, histories, root causes, and immediate stressors are essential.

(3.8) Peacebuilding creates spaces where people interact in new ways, expanding experience and honing new means of communication.

(3.9) Peacebuilding heals trauma, promotes justice and transforms relationships.

(3.9) Peacebuilding requires capacity and relationship building at multiple levels.

\subsection{Institutional Definitions of Peacebuilding.}

A. Conflict Information Consortium, University of Colorado: Peacebuilding is a process that facilitates the establishment of durable peace and tries to prevent the recurrence of violence by addressing root causes and effects of conflict through reconciliation, institution building, and political as well as economic transformation. This consists of a set of physical, social, and structural initiatives that are often an integral part of postconflict reconstruction and rehabilitation.

B. Global Partnership for the Prevention of Armed Conflict: Peacebuilding involves addressing social and political sources of conflict as well as reconciliation. 
C. Organization for Economic Cooperation and Development: [Peacebuilding] includes activities designed to prevent conflict through addressing structural and proximate causes of violence, promoting sustainable peace, delegitimizing violence as a dispute resolution strategy, building capacity within society to peacefully manage disputes, and reducing vulnerability to triggers that may spark violence.

D. School of Conflict Analysis and Resolution at George Mason University: Peacebuilding is a term used within the international development community to describe the processes and activities involved in resolving violent conflict and establishing sustainable peace. It is an overarching concept that includes conflict transformation, restorative justice, trauma healing, reconciliation, development, and leadership, underlain by spirituality and religion. It is similar in meaning to conflict resolution but highlights the difficult reality that the end of a conflict does not automatically lead to peaceful, stable social or economic development. Several national and international organizations describe their activities in conflict zones as peacebuilding.

E. United Nations Development Program: Peacebuilding involves a range of measures targeted to reduce the risk of lapsing or relapsing into conflict by strengthening national capacities at all levels for conflict management, and laying the foundations for sustainable peace and development. Peacebuilding strategies must be coherent and tailored to the specific needs of the country concerned, based on national ownership, and should comprise a carefully prioritized, sequenced, and therefore a relatively narrow set of activities aimed at achieving the above objectives. This office works specifically with peacebuilding in the context of conflict prevention.

F. United Nations: Peacebuilding Support Office: Peacebuilding is rather the continuum of strategy, practices, and activities aimed at sustaining peace over the long-term with a clear focus on reducing chances for the relapse into conflict.... It is useful to see peacebuilding as a broader policy framework that strengthens the synergy among the related efforts of conflict prevention, peacemaking, peacekeeping, recovery, and development, as part of a collective and sustained effort to build lasting peace. This office works specifically with peacebuilding in the context of postconflict reconstruction.

G. United States Institute of Peace: Originally conceived in the context of post-conflict recovery efforts to promote reconciliation and reconstruction, the term peacebuilding has more recently taken on a broader meaning. It may include providing humanitarian relief, protecting human rights, ensuring security, establishing nonviolent modes of resolving conflicts, fostering reconciliation, providing trauma healing services, repatriating refugees and resettling internally displaced persons, supporting broad-based education, and aiding in economic reconstruction. As such, it also includes conflict prevention in the sense of preventing the recurrence of violence, as well as conflict management and post-conflict recovery.

\section{Research}

In the second half of the twentieth century, in the area of international relations, multiple studies and research on conflict management were carried out without limit of economic and human resources. Motivated by the optimization of conflict resolution to avoid new wars and stabilize International Peace, the search produced results that applied to the objective of achieving internal social Peace, improving interaction and resolving, without the use of violence, conflicts derived from the inevitable incompatibility of pretensions. 
The study of the conflict has brought to light "two great gibberish":

- The first has as protagonist the Theory of Conflicts, which shows the judicial system of conflict resolution as a violent method, comparable to what war means internationally.

- The second resides in discovering that the legal order that regulates social coexistence supposes the immediate classification of all the possible conducts of its members into two large groups; conducts without sanctions that the law calls "allowed" and conducts threatened with sanctions that the law calls "prohibited".

\section{Discussion}

In a larger sense, peacebuilding involves a transformation toward more manageable, peaceful relationships and governance structures - the long-term process of addressing root causes and effects, reconciling differences, normalizing relations, and building institutions that can manage conflict without resort to violence. The US Government does not have a publicly available definition of peacebuilding, other than the definition provided by USIP.

As we can see there are many distinct ways to understand peacebuilding. Therefore it is not surprising how often participants in the peace process have allowed themselves to be diverted by other concerns (their interests or reputations of particular persons, groups, enterprises, countries, etc). It seems obvious, but the most important goal in the process must always be peace, peacebuilding. It is generally agreed that moving forwards peacebuilding goes beyond problem-solving or conflict management.

Peacebuilding initiatives try to fix the core problems that underlie the conflict and change the patterns of interaction of the involved parties. The central task of peacebuilding is to create positive peace, a "stable social equilibrium in which the surfacing of new disputes does not escalate into violence and war" (Haugerudbraaten 1998). Sustainable peace is characterized by the absence of direct, cultural and structural violence (Galtung, 2013). The main aim to move people from a condition of extreme vulnerability and dependency to one of selfsufficiency and well-being.

In the interests of keeping this article and also my thought in a reasonable extension and deep, this article primarily focuses on the narrower use of the term peacebuilding, that is to say, a process that facilitates the establishment of durable peace and tries to prevent the recurrence of violence by addressing root causes and effects of conflict through reconciliation, institution building, and political as well as economic transformation (Boutros-Ghali, 1995).

Peacebuilding includes three aspects: Personal, Interpersonal and Structural, which derive from a three-dimensional work level: Direct, Structural and Cultural.

According to John Paul Lederach, another key scholar in the field of peace studies, peacebuilding is more than post-accord reconstruction, it is:

[...] understood as a comprehensive concept that encompasses, generates, and sustains the full array of processes, approaches, and stages needed to transform conflict toward more sustainable, peaceful relationships. The term thus involves a wide range of activities that both precede and follow formal peace accords. Metaphorically, peace is seen not merely as a stage in time or a condition. It is a dynamic social construct.(Lederach, 1997).

Lederach coined the term conflict transformation as an approach to an ongoing process of change from negative to positive relations, behavior, attitudes, and structures. "A sustainable transformative approach suggests that the key lies in the relationship of the involved parties, 
with all that the term encompasses at the psychological, spiritual, social, economic, political and military levels. "(Lederach, 1997, p. 75).

As he said, the infrastructure for peacebuilding means that "We are oriented toward the building of relationships that in their totality form new patterns, processes, and structures. "(Lederach, 1997, pp. 84-85).

Galtung's transcend model recognizes three levels of violence (Conforti, 2018, pp. 186-188):

A. Direct violence: consists of events. It is the result of the sum of visible damage (death, injury, refugees, material destruction, etc.) and invisible damage (trauma, hatred, desire for revenge, etc.), which includes both physical and verbal form.

For example, the abolition of apartheid does not necessarily mean the resolution of social, political, racial andethnic questions prevailing in South Africa, as Babacar Diakhaté remarks "In Post-Apartheid South Africa women suffer much from gender and racial discrimination. The lack of jobs leads young South Africans to get indulge in prostitution and assaulting." (Diakheté, 2019, p. 4).

B. Cultural violence: it is invariably given the slow transformation of the basic culture. It corresponds to the cultural aspects (religion, ideology, language, scientific knowledge, etc.) that come to "legitimize" the other two types of violence, in the sense that it makes them appear as correct according to our cultural parameters.

For example, regarding the Language, Akinwamide said:

Language affects the thought and behaviour of human beings. The attitude of a person speaking more than one language is not the same as others who speak just one language. The first person can comment on issues from different viewpoints. He/she can see and evaluate the events in a better and broader perspective as against the narrow view through one language. As knowledge gives insight, security, peace and confidence to human beings, ignorante causes suspicion, repulse and mistrust. Ability to converse in other people language means entering a world of interactive thinking, observing differently, accepting different life-styles, harmonizing and clarifying the obscurities which are the root cause of prejudice and prolonged conflicts. (Akinwamide, 2018, p. 2).

Language divide in: political party formation,religious affiliation, societal interaction, appointment disposition,admision into institutions, news circulation, music production, nacional policy interpretation, and, resturctural agitation.

C. Structural violence: it is characterized as a process with highs and lows. It is that which materializes in injustice and inequality as a consequence of one's social structure, whether within society or a group or community of societies.

For example, regarding the claims of nationhood developmental needs linked with education, Dzvimbo remarks:

Since the attainment of independence by most African countries from their colonial subjugation, they were faced with a mammoth task of nation building and education was foremost viewed as a transformative tool for development (Merryfield and Tlou, 1995; Moyo and Yeros, 2007). On the other hand, this was actually a predicament in that, African countries inherited oppressive and racially skewed educational systems with incapacitated human development capacity. However, in trying to correct these injustices and enhance transformation, dual contradictory paradigm sevolved, one was based on the role of educational transformation, liberating and empowerment. In this regard, this perspective did put emphasis on the discourse which would assist pupils to conceptualise their societal values in order to transform and focus on innovation as well as experimentation (Nziramasanga, 1999). On the contrary, education was seen as skills development and 
preparation for the outsider world. This overview puts emphasis on the enlightenment of students with specific skills to enable them to effectively suit into the human development market (Nabudere, 2007; Omatseye and Omatseye, 2008). Relevance to national needs entails viewing a minority perspective educational transformation in the lenses of empowering and liberating the citizenry [...] critics have objected the notion of relevante to the country's needs and aspirations which have been actually construed in terms of improving the standard of living and development of the continent's spiritual and material lives [...].(Dzvimbo, 2019, p. 6).

The transcend method recognizes three stages in the life of conflict: a) before, b) during and c) after violence. These stages are separated from each other by the breakdown of hostilities and the ceasefire respectively. To resolve the conflict, the parties must develop the notions of the 3Rs (reconciliation, reconstruction, and resolution), that is:

A. Reconstruction (after violence): the primary objective of which is to heal the open wounds caused by the confrontation between the parties and to repair the material damage.

B. Reconciliation (of the parties): this is intended to undo the meta-conflict.

C. Resolution (of the underlying conflict): it seeks to create the necessary conditions to solve the original conflicts.

The work of the conflict operator must be aimed at creating Peace, for that it must be able to manage conflicts with:

A. Empathy: with all parties to the conflict, the mediator must listen to all parties and consider all positions, only then will he be able to understand how the situation has occurred. The method defines empathy as the act of sharing cognitively and emotionally, of feeling and understanding the passions of others, without necessarily implying agreement with them. All the parties involved in the conflict must be able to speak, listen and understand each other, only in this way can tolerance towards the diversity of thoughts and actions be generated.

B. Creativity: the mediator must know the parties, discover their objectives (even the hidden ones) and find their contradictions, this will allow him to distinguish between legitimate objectives of those that are not (although the parties present them as legitimate and totally incompatible), and once this distinction is made, he must focus on building a bridge between the legitimate objectives, for this it is important that the mediator can build a framework of trust.

C. Non-violence: it is convenient to take care of the language, to use a positive or neutral language since the language as a creator of reality can open and close the door towards an agreement. The mediator has to generate a dialogue that seeks to lead the parties to something new so that the parties can talk and wonder what each of them needs.

\section{Conclusion}

It is important to note the differences between peacebuilding with the more traditional strategies of peacemaking (this is the diplomatic effort to end the violence between the conflicting parties -move the antagonist towards nonviolent dialogue, and eventually reach a peace agreement), and the peacekeeping (which is a third-party intervention -often carried out military forces- to assist parties in transitioning from violent conflict to peace by separating the fighting parties and keeping them apart, so it does not only provide security but also facilitate other non-military initiatives). 
Finally, it is fair to say that the peacebuilding concept adopted in this article is based on the idea that peacebuilding includes tangible ("visible," quantifiable) and intangible ("invisible," qualitative) dimensions. The tangible dimension consists of such things as the number of weapons destroyed, soldiers demobilized, jobs created, or dialogues held. The intangible dimension includes such phenomena as reconciliation between former antagonists, trust in public institutions, and new forms of dispute resolution.

\section{References}

Akinwamide. T. K. (2018). Bridging Across Language Divide for Growth and PeacefulCoexistence: A Panacea for Economic Recessionin a Multilingual Nigeria. Budapest International Research and Critics Institute-Journal (BIRCI-Journal). Volume I, No 3, October 2018, pp. 01-06e-ISSN: 2615-3076 (Online), p-ISSN: 2615-1715(Print).

Alliance for Peacebuilding. (2013). Selected definitions of Peacebuilding. August 12, 2013, Peacebuilding News. 2013. https://allianceforpeacebuilding.org/2013/08/selecteddefinitions-of-peacebuilding/> (Visited July 24, 2019).

Boutros-Ghali, B. (1995).An Agenda for Peace. New York, U.S: United Nations.

Conforti, O. D. F. (2018). Construcción de Paz. Diseño de intervención en conflictos. $3^{\circ} \mathrm{Ed}$. Madrid, Spain: Dykinson.

Conforti, O. D. F. (2019). Building Peace. Research, Theury and Practice in the Criminal Law. Alicante, Spain: Acuerdo Justo.

Diakhaté, B. (2019). Racial Politics and Sexual Violence in Post-ApartheidContemporary South Africa in John Maxwell Coetzee'sDisgrace (2000). Britain International of Humanties and Social Sciences (BIoHS) Journal, 1-5.

Dzvimbo M.A. (2019). The Dynamics of Education on the Development of an IntellectualCitizenry in Africa. Budapest International Research and Critics in Linguistics and Education (BirLE) Journal, 1-9.

Galtung, J.(1976).Three Approaches to Peace: Peacekeeping, Peacemaking, and Peacebuilding.Peace, War and Defense: Essays in Peace Research, Vol. II, ed. Johan Galtung, pp. 297-298. Copenhagen: Christian Ejlers.

Galtung, J. (1998). Peace by peaceful means: peace and conflict, development and civilization. New York: Sage.

Galtung, J. (2010).A Theory of Conflict. Kolofon Press.

Galtung, J. (2013).A Theory of Peace. Kolofon Press.

Galtung, J. (2017).The Art of Peace. Kolofon Press.

Galtung, I. (2019). Keynote Speech, International Peace Research Association (IPRA) 7 Jan 2006. \#607 Johan Galtung. Transcend Media Service. Editorial, 7, Oct. 2019.

Haugerudbraaten, H.(1998). Peacebuilding: Six dimensions and two concepts.African Security Review, 17-26.

Lederach, J. P. (1995). Conflict Transformation in Protracted Internal Conflicts: The Case for a Comprehensive Framework. Conflict Transformation, ed. Kumar Rupesinghe. New York: St. Martin's Press/ Basingstoke: Macmillan, 201-222.

Lederach, J. P. (1997). Building Peace: Sustainable Reconciliation in Divided Societies. Washington, D.C., U.S. Institute of Peace Press.

Santa Barbara J., Galtung J., and Perlman D. (2012). Reconciliation. Clearing the Past. Building a Future. Kolofon Press. 